\title{
Electrochemical Hydrogen Peroxide Sensor Based on Macroporous Silicon
}

\author{
Naif H. Al-Hardan ${ }^{1, *(1)}$, Muhammad Azmi Abdul Hamid ${ }^{1, *}$, Roslinda Shamsudin ${ }^{1}$, \\ Ensaf Mohammed AL-Khalqi ${ }^{1}$, Lim Kar Keng ${ }^{1}$ and Naser M. Ahmed ${ }^{2}$ \\ 1 School of Applied Physics, Faculty of Science and Technology, Universiti Kebangsaan Malaysia (UKM), \\ Bangi 43600, Malaysia; linda@ukm.edu.my (R.S.); p92953@siswa.ukm.edu.my (E.M.A.-K); \\ karkeng.iamkklim@gmail.com (L.K.K.) \\ 2 School of Physics, Universiti Sains Malaysia (USM), Penang 11800, Malaysia; naser@usm.my \\ * Correspondence: naif@ukm.edu.my (N.H.A.-H.); azmi@ukm.edu.my (M.A.A.H.); \\ Tel.: +60-3-989-217-002 (N.H.A.-H. \& M.A.A.H.)
}

Received: 10 December 2017; Accepted: 14 February 2018; Published: 28 February 2018

\begin{abstract}
Macroporous silicon was prepared through an anodization process; the prepared samples showed an average pore size ranging from 4 to 6 microns, and the depth of the pores in the silicon wafer was approximately 80 microns. The prepared samples were tested for hydrogen peroxide $\left(\mathrm{H}_{2} \mathrm{O}_{2}\right)$ concentrations, which can be used for industrial and environmental sensing applications. The selected $\mathrm{H}_{2} \mathrm{O}_{2}$ concentration covered a wide range from 10 to $5000 \mu \mathrm{M}$. The tested samples showed a linear response through the tested $\mathrm{H}_{2} \mathrm{O}_{2}$ concentrations with a sensitivity of $0.55 \mu \mathrm{A \mu M} \mathrm{M}^{-1} \cdot \mathrm{cm}^{-2}$ and lower detection limits of $4.35 \mu \mathrm{M}$ at an operating voltage of $5 \mathrm{~V}$. Furthermore, the electrode exhibited a rapid response with a response time of ca. two seconds. Furthermore, the prepared sensor showed a reasonable stability over a one-month time period.
\end{abstract}

Keywords: macroporous silicon; hydrogen peroxide; electrochemical sensors; amperometric sensors

\section{Introduction}

Macroporous silicon (MPS) has attracted the attention of several groups, owing to the well-known advantages of its large surface area and biocompatibility [1], as well as its showing promising behavior in several advanced applications, such as gas sensing [2,3], $\mathrm{pH}$ sensors [4], biochips [5], CMOS devices [6], drug delivery devices [1], biosensors [7,8], and in fuel cell devices [9] and waveguides [10]. Furthermore, it can be simply integrated with silicon technology processes [11]. Several published works have shown the excellent behavior for bio-sensing applications of porous silicon, which make it a promising candidate in the field of biosensors [11,12].

The important role of hydrogen peroxide $\left(\mathrm{H}_{2} \mathrm{O}_{2}\right)$ in different areas, such as the food industry [13], manufacturing processes [14], and environmental protection [15] has been reported earlier. Furthermore, several neurodegenerative diseases, such as Parkinson's and Alzheimer's, are connected to excess amounts of $\mathrm{H}_{2} \mathrm{O}_{2}$ [16-19], and it also contributes to the formation of acid rain [20]. $\mathrm{H}_{2} \mathrm{O}_{2}$ has become one of the main substances in the monitoring of biological processes [21]. For these reasons, the determination of $\mathrm{H}_{2} \mathrm{O}_{2}$ levels has become a crucial task in various fields, including physiology, pathology, and the environment. Hence, sensitive and accurate determination of $\mathrm{H}_{2} \mathrm{O}_{2}$ in different environments is required.

Various effective methods have been proposed and used to determine $\mathrm{H}_{2} \mathrm{O}_{2}$ concentrations, including titrimetric [22], spectrophotometry [23], chemi-luminescence, chromatography [24] and electrochemical methods [25,26]. However, most of these methods are bulky, use expensive [27] reagents, and require long analysis times. The electrochemical method has been in the spotlight for its cost-effective characteristics, low detection limit, high sensitivity, fast response, and excellent 
selectivity $[27,28]$. Most prepared electrodes under test that have been used for the electrochemical method are modified by immobilization with catalytic substances that show better sensitivity and selectivity $[25,29,30]$. Unfortunately, these types of electrodes face some drawbacks as well, such as high cost, instability, and inability to work effectively under proper conditions [28].

Previously, we reported on the application of zinc oxide ( $\mathrm{ZnO}$ ) nanorods for $\mathrm{H}_{2} \mathrm{O}_{2}$ detection [31], the prepared $\mathrm{ZnO}$ nanorods showed a linear response in the range of $10 \mu \mathrm{M}$ to $700 \mu \mathrm{M}$ with a sensitivity of $295 \mathrm{nA} \mathrm{\mu M}{ }^{-1} \cdot \mathrm{cm}^{-2}$. The low-range response may be due to the degradability of $\mathrm{ZnO}$ once it is in contact with the analyte [32,33], or to the limit in the active sites. On the other hand, porous silicon has shown more stable performance in several biosensing applications. Here, we report on the application of a non-enzymatic $\mathrm{H}_{2} \mathrm{O}_{2}$ sensor based on MPS for environmental and industrial applications. The electrode is tested in $\mathrm{H}_{2} \mathrm{O}_{2}$ dissolved in deionized water covering the range between $10 \mu \mathrm{M}$ and $5000 \mu \mathrm{M}$.

\section{Materials and Methods}

The macroporous silicon (MPS) samples used in this study were fabricated using an anodization processor. The processor was explained in detail in our previous published work [4]. In summary, an n-type silicon wafer (Si) with (100) orientation and resistivity value of $\sim 1-10 \Omega \cdot \mathrm{cm}$ was cut into four pieces. The samples were then cleaned via the RCA (Radio Corporation of America) method. Then, the samples were inserted into a homemade Teflon electrochemical cell. The polished side of the $\mathrm{Si}$ sample faces the cathode electrode (Pt). The cell is filled with a mixture of hydrofluoric acid (HF 48\%) and ethanol $\left(\mathrm{C}_{2} \mathrm{H}_{5} \mathrm{OH} 98 \%\right)$ at ratio of 1:4 $v / v$. The system was then supplied with a constant current density of $30 \mathrm{~mA} / \mathrm{cm}^{2}$ for $15 \mathrm{~min}$ under illumination from a $100 \mathrm{~W}$ tungsten lamp. The fabricated MPS samples were then rinsed with deionized water and dried with a nitrogen gas flow.

The surface morphology and cross-section details of the fabricated MPS were investigated via field emission scanning electron microscopy (FE-SEM) Zeiss SUPRA 55-VP (Carl Zeiss AG, Oberkochen, Germany).

From the prepared MPS samples, small pieces were scribed and mounted on a copper strip from a printed circuit board (PCB). Conductive wire was connected between the Si wafer and the copper strip using a conductive paste. Epoxy resin was employed to encapsulate the MPS and the copper line of the PCB. The prepared electrodes were left to cure for at least $24 \mathrm{~h}$ at room temperature. An area of approximately $0.55 \mathrm{~cm} \times 0.35 \mathrm{~cm}$ free of epoxy was used as a sensing window.

The sensing characteristics of the fabricated MPS electrode toward different concentrations of $\mathrm{H}_{2} \mathrm{O}_{2}$ were tested by employing the 6517A electrometer (Keithley Instruments, Inc., Cleveland, OH, USA), attached to a host personal computer via GPIB-USB cable. LabView software was utilized to control the electrometer and save the result data for further analysis. The manufactured MPS electrode was considered as the working-electrode, and a platinum wire (diameter of $0.5 \mathrm{~mm}$ ) as the counter-electrode. The measured current in the current-voltage (I-V) test was obtained in the voltage range between 0 and $6 \mathrm{~V}$. The measurements were repeated at least twice for each step, and the average of the measurements was calculated.

The $\mathrm{H}_{2} \mathrm{O}_{2}$ stock solution was prepared by mixing a given amount of $\mathrm{H}_{2} \mathrm{O}_{2}\left(30\right.$ wt. \% in $\mathrm{H}_{2} \mathrm{O}$ ) from Sigma-Aldrich in double-deionized water (DIW). Then the prepared stock was diluted to the desired concentrations. The concentration of the $\mathrm{H}_{2} \mathrm{O}_{2}$ used to test the manufactured MPS electrode was in the range of $10 \mu \mathrm{M}$ to $5000 \mu \mathrm{M}$. The measurements were performed under ambient atmospheric conditions $\left(23^{\circ} \mathrm{C}\right.$, and $50 \%$ relative humidity).

\section{Results}

Initially, a visual inspection at the surface of the fabricated MPS shows the formation of a smooth light brown color membrane on the Si wafer surface, which confirms the formation of the pores. The micro image of the fabricated MPS sample is depicted in Figure 1. The nearly uniform distribution of the formed pores on the Si surface is clear from the image (Figure 1a). The average pore size was 
in the range of 4-6 microns. On the other hand, a cross-section image of the same fabricated sample reveals that the depth of the fabricated MPS was approximately 80 microns (Figure 1c), which makes it a suitable candidate for amperometry-based electrochemical sensors [11]. In addition, Figure 1b,d depicts a larger magnification of the above images, it also shows the large surface area of the pores, which result in a higher exposed surface area of the MPS with the analyte.
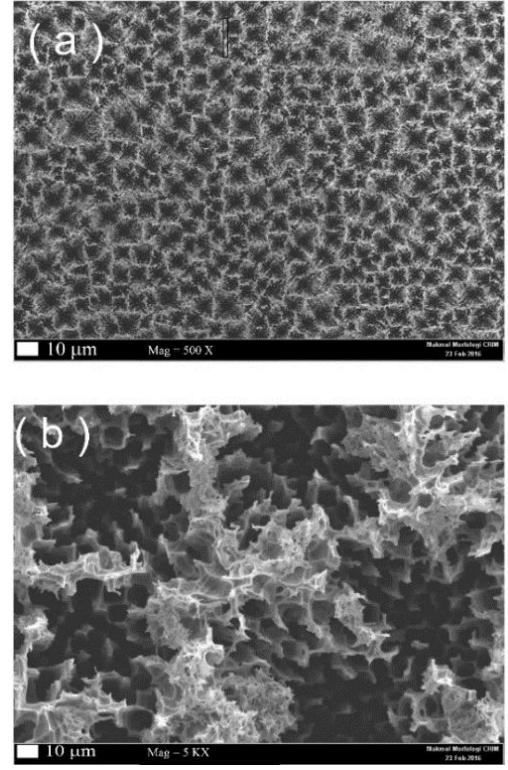
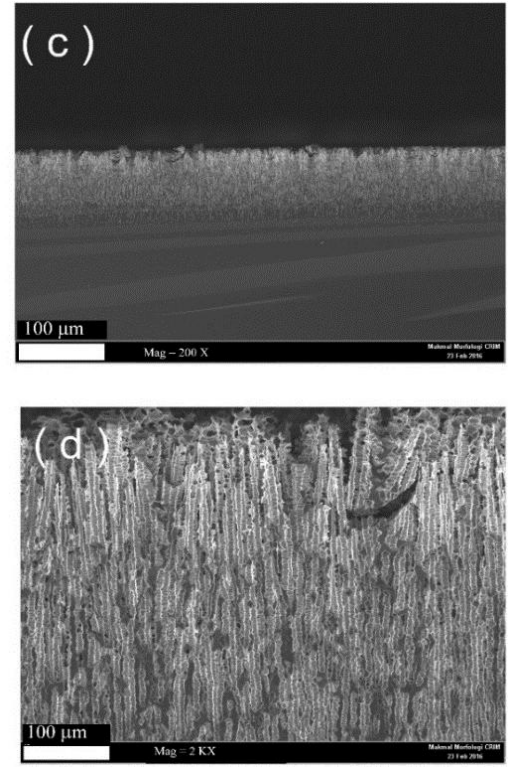

Figure 1. The FE-SEM image of the prepared MPS surface: (a) the surface; (b) higher magnification of the MPS surface; (c) the cross-section of the prepared MPS; and with higher magnification (d).

To investigate the sensing ability of the fabricated MPS with respect to different $\mathrm{H}_{2} \mathrm{O}_{2}$ concentrations, the current was measured versus $\mathrm{H}_{2} \mathrm{O}_{2}$ at a concentration of $5000 \mu \mathrm{M}$. Figure 2 presents the I-V behavior of the fabricated MPS electrode. The figure reveals the difference between the measured current density in the DIW and $5000 \mu \mathrm{M} \mathrm{H}_{2} \mathrm{O}_{2}$ stock solution. It is obvious that the current density is drastically increased as the environment changes from the DIW to the $\mathrm{H}_{2} \mathrm{O}_{2}$ solution. This increase in the current density implies the excellent electro-catalytic activity of the fabricated MPS electrode for the oxidation of $\mathrm{H}_{2} \mathrm{O}_{2}$ diluted in DIW. Furthermore, it proves the modification in the electrical properties of the fabricated MPS electrode with the introduction of $\mathrm{H}_{2} \mathrm{O}_{2}$ molecules.

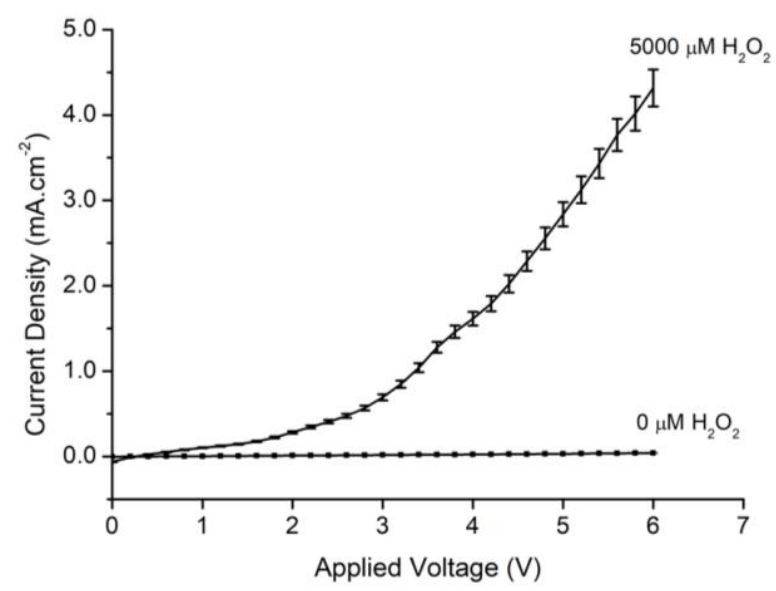

Figure 2. The I-V characterization of MPS versus Pt electrodes with $5000 \mu \mathrm{M} \mathrm{H}_{2} \mathrm{O}_{2}$ and pure deionized water. 
For more details on the I-V behavior of the manufactured MPS electrode, the electrode was examined with different $\mathrm{H}_{2} \mathrm{O}_{2}$ amounts. The stock solution was diluted in the range from $5000 \mu \mathrm{M}$ to $10 \mu \mathrm{M}$, and the result currents were recorded. Figure 3 depicts the I-V characteristics, and the gradual increase in the current density as the $\mathrm{H}_{2} \mathrm{O}_{2}$ concentrations is increased is noteworthy. The inset shows the measured current density at low $\mathrm{H}_{2} \mathrm{O}_{2}$ concentrations from DIW to $100 \mu \mathrm{M}$.

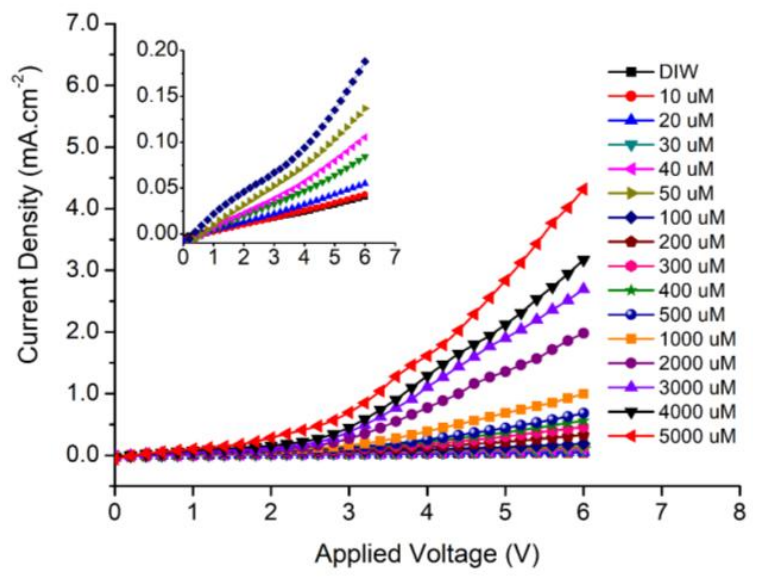

Figure 3. The current density versus the applied voltage with different $\mathrm{H}_{2} \mathrm{O}_{2}$ concentrations. The inset figure shows the details of low $\mathrm{H}_{2} \mathrm{O}_{2}$ concentrations (DIW to 100) $\mu \mathrm{M}$.

It is known that the oxygen molecules [34,35] dissolved in water are adsorbed (chemisorbed) on the MPS active sites; consequently, it converts to active oxygen ions with the capture of electrons from the surface of MPS. This can be understood through the following reactions [31,35]:

$$
\begin{gathered}
\mathrm{O}_{2}(\text { dissolved }) \rightarrow \mathrm{O}_{2}(\text { adsorbed }) \\
\mathrm{O}_{2}(\text { adsorbed })+e^{-} \rightarrow \mathrm{O}_{2}^{-}(\text {adsorbed })
\end{gathered}
$$

Once the $\mathrm{H}_{2} \mathrm{O}_{2}$ is added to the water, the active oxygen ions will react with the analyte. As a result, this will generate free electrons, as can be seen in the following reaction:

$$
2 \mathrm{H}_{2} \mathrm{O}_{2}+\mathrm{O}_{2}^{-} \text {(adsorbed) } \rightarrow 2 \mathrm{H}_{2} \mathrm{O}+2 \mathrm{O}_{2}+2 e^{-}
$$

Subsequently, the measured current will increase with the addition of more $\mathrm{H}_{2} \mathrm{O}_{2}$, which results in the generation of more free charge carriers.

The effect of applied voltage at $4 \mathrm{~V}, 5 \mathrm{~V}$, and $6 \mathrm{~V}$ on the current values measured at various amounts of $\mathrm{H}_{2} \mathrm{O}_{2}$ can be seen in Figure 4. The increase of the current with the applied voltage is noticeable.

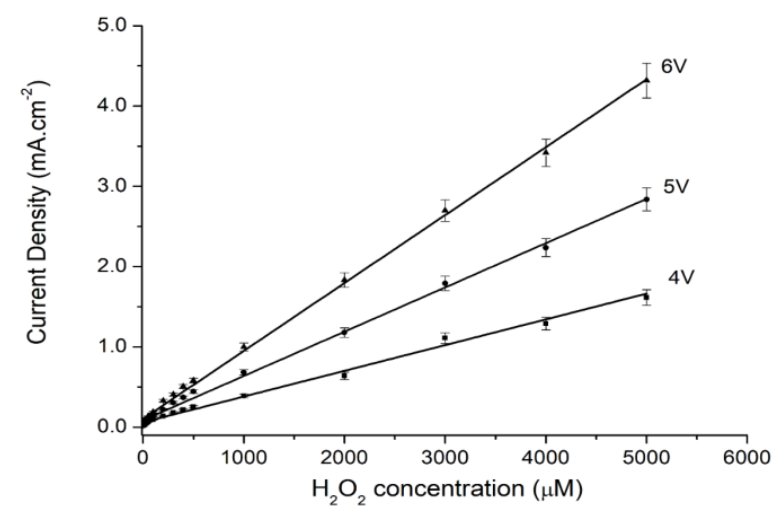

Figure 4. The current density versus the applied voltage with different $\mathrm{H}_{2} \mathrm{O}_{2}$ concentrations. 
From the gradients of each applied voltage versus $\mathrm{H}_{2} \mathrm{O}_{2}$ concentrations at each applied voltage, the sensitivity of the MPS for $\mathrm{H}_{2} \mathrm{O}_{2}$ can be calculated. In Table 1, the results of the sensitivity and the lower detection limits (LODs) of the fabricated MPS electrodes are tabulated. The tabulated results reveal that with an increase in the applied voltage from $4 \mathrm{~V}$ to $6 \mathrm{~V}$, the sensitivity increased from 0.32 to $0.85 \mathrm{Ma} \mu \mathrm{M}^{-1} \cdot \mathrm{cm}^{-2}$. On the other hand, the LOD shows an insignificant change in value at the same operating voltage.

Table 1. Depicts the sensitivity and LOD with the applied voltage values.

\begin{tabular}{ccc}
\hline Applied Voltage (V) & Sensitivity $\left(\boldsymbol{\mu} \mathbf{A} \mu \mathbf{M}^{-\mathbf{1}} \cdot \mathbf{c m}^{-\mathbf{2}}\right)$ & LOD $(\mu \mathrm{M})(\mathrm{SNR}=\mathbf{3})$ \\
\hline 4 & $0.32 \pm 0.082$ & 4.38 \\
5 & $0.55 \pm 0.018$ & 4.35 \\
6 & $0.85 \pm 0.023$ & 3.61 \\
\hline
\end{tabular}

The dynamic current-time (I-t) behavior was also tested for the manufactured electrode. The stock solution was diluted so that each drop of the diluted sample was equivalent to $10 \mu \mathrm{M}$ in a $20 \mathrm{~mL}$ DIW cell. The applied voltage was fixed at $5 \mathrm{~V}$, and the solution was continuously stirred. Figure 5 reveals the I-t behavior of the manufactured MPS electrode, the rapid response at each drop of $\mathrm{H}_{2} \mathrm{O}_{2}$ is noticeable, with a response time of approximately two seconds.

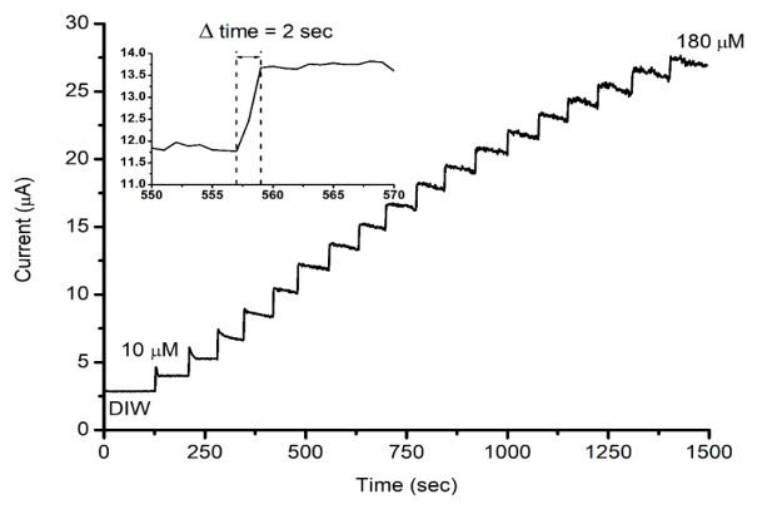

Figure 5. The current response versus time at an applied voltage of $5 \mathrm{~V}$ with accumulated concentrations of $\mathrm{H}_{2} \mathrm{O}_{2}$, each step is $10 \mu \mathrm{M}$. The inset shows the response time of approximately $2 \mathrm{~s}$ at each step.

Figure 6, on the other hand, reveals the response of the manufactured MPS electrode at higher $\mathrm{H}_{2} \mathrm{O}_{2}$ concentrations. The electrode shows a stable current output as the $\mathrm{H}_{2} \mathrm{O}_{2}$ concentration increases to $5000 \mu \mathrm{M}$.

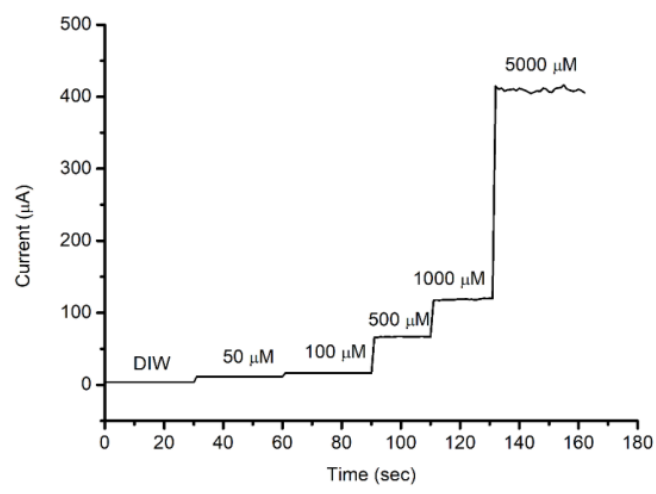

Figure 6. The current response versus time at an applied voltage of $5 \mathrm{~V}$ with concentrations of $\mathrm{H}_{2} \mathrm{O}_{2}$ in the range of 0 to $5000 \mu \mathrm{M}$. 
The manufactured MPS electrode shows a promising behavior for sensor work in industrial and environmental applications for the detection of $\mathrm{H}_{2} \mathrm{O}_{2}$ amounts. In Table 2, several materials are shown for comparison with the results obtained in this study. The results in this work were within the range of different materials and compounds tested for $\mathrm{H}_{2} \mathrm{O}_{2}$. Despite there being many materials used to test $\mathrm{H}_{2} \mathrm{O}_{2}$ concentrations, most of those materials are expensive or have time-consuming preparation processes. This make MPS a good competitive material on account of its simple preparation and its compatibility with IC process technology.

Table 2. Some materials used for $\mathrm{H}_{2} \mathrm{O}_{2}$ detection as compared to this study.

\begin{tabular}{lccc}
\hline \multicolumn{1}{c}{ Electrode } & Detection Limit $(\mu \mathbf{M})$ & Linea Range $(\mu \mathbf{M})$ & References \\
\hline $\mathrm{Pt} / \mathrm{TeO}_{2}-\mathrm{NWs}$ & 0.60 & $2-16,000$ & {$[26]$} \\
$\mathrm{CdOx}$ in EIS structure & 1 & $1-200$ & {$[36]$} \\
$\mathrm{Co}_{3} \mathrm{O}_{4} \mathrm{NW}$ & 2.4 & $15-675$ & {$[37]$} \\
$\mathrm{Pt} \mathrm{NP}$ & 1.23 & $5-2000$ & {$[38]$} \\
$\mathrm{Ag} \mathrm{NW}$ & 29.2 & $100-3100$ & {$[39]$} \\
$\mathrm{MoS} 2 \mathrm{NP}$ & 0.002 & $5-100$ & {$[40]$} \\
$\mathrm{CuO} / \mathrm{Cu}$ foil & 16.7 & $42.5-40,000$ & {$[41]$} \\
$\mathrm{Pt} / \mathrm{TiO}_{2} /$ single-walled carbon nanotube & 0.73 & $0-3500$ & {$[42]$} \\
$\mathrm{Cu}$ porous Si & 0.27 & $500-3780$ & {$[43]$} \\
$\mathrm{MPS} /$ copper PCB & 4.35 & $10-5000$ & This study \\
\hline
\end{tabular}

In addition, the long-term stability of the manufactured MPS was tested at specific $\mathrm{H}_{2} \mathrm{O}_{2}$ concentrations. The results are shown in Figure 7, which shows a stable behavior for a period time of one month.

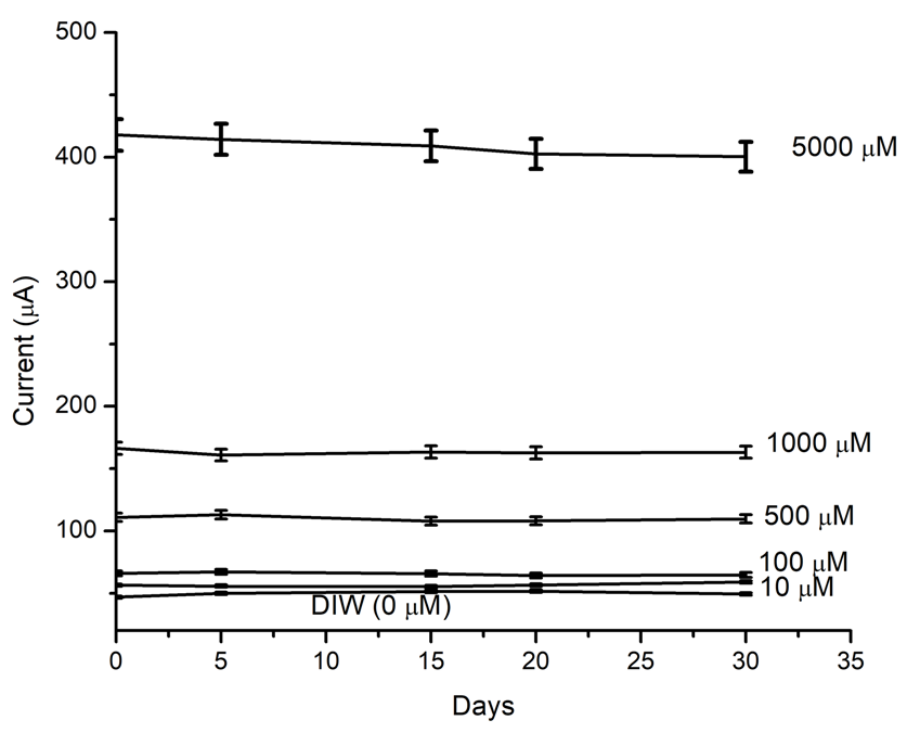

Figure 7. The stability of the measured current for one month at an applied voltage of $5 \mathrm{~V}$. The concentrations of $\mathrm{H}_{2} \mathrm{O}_{2}$ were $0,10,100,500,1000$, and $5000 \mu \mathrm{M}$.

\section{Conclusions}

In summary, we report the application of MPS for $\mathrm{H}_{2} \mathrm{O}_{2}$ sensing. The manufactured sensor shows excellent behavior in terms of its linearity within a wide concentration range of the analyte (10 to $5000 \mu \mathrm{M})$, sensitivity $\left(0.55 \mu \mathrm{A} \mu \mathrm{M}^{-1} \cdot \mathrm{cm}^{-2}\right)$, and LOD $(4.35 \mu \mathrm{M})$, with a fast response time of two seconds. Furthermore, the manufactured electrode shows a stable behavior over a time period of one month.

Acknowledgments: This work was supported by the Universiti Kebangsaan Malaysia (UKM) through short-term grant number DIP 2016-029 (UKM). The authors are also thankful to the Center for Research and Instrumentation Management (CRIM) at UKM for providing the FE-SEM measurements. 
Author Contributions: N.H.A.-H., M.A.A.H., and R.S. contributed equally to this work by conceiving and designing the experiments; N.H.A.-H. and E.M.A.-K. performed the experiments. N.H.A.-H., M.A.A.H. and R.S. analyzed the data and drafted the manuscript. N.H.A.-H. and M.A.A.H. revised and proofread the draft manuscript. L.K.K. and N.M.A. gave technical support and conceptual advice.

Conflicts of Interest: The authors declare no conflict of interest.

\section{References}

1. Anglin, E.J.; Cheng, L.; Freeman, W.R.; Sailor, M.J. Porous silicon in drug delivery devices and materials. Adv. Drug Deliv. Rev. 2008, 60, 1266-1277. [CrossRef] [PubMed]

2. Wang, Y.; Park, S.; Yeow, J.T.W.; Langner, A.; Müller, F. A capacitive humidity sensor based on ordered macroporous silicon with thin film surface coating. Sens. Actuators B Chem. 2010, 149, 136-142. [CrossRef]

3. Galeazzo, E.; Peres, H.E.M.; Santos, G.; Peixoto, N.; Ramirez-Fernandez, F.J.; Ramirez-Fernandez, F.J. Gas sensitive porous silicon devices: Responses to organic vapors. Sens. Actuators B Chem. 2003, 93, 384-390. [CrossRef]

4. Al-Hardan, N.H.; Abdul Hamid, M.A.; Naser, M.A.; Azman, J.; Roslinda, S.; Norinsan, K.O.; Lim, K.K.; Weesiong, C.; Al-Rawi, H.N.; Ahmed, N.; et al. High Sensitivity pH Sensor Based on Porous Silicon (PSi) Extended Gate Field-Effect Transistor. Sensors 2016, 16, 839. [CrossRef] [PubMed]

5. Föl, H.; Carstensen, M.; Christophersen, J.; Hasse, G. Formation and application of porous silicon. Mater. Sci. Eng. R Rep. 2002, 39, 93-141. [CrossRef]

6. Barillaro, G.; Strambini, L.M. An integrated CMOS sensing chip for $\mathrm{NO}_{2}$ detection. Sens. Actuators B Chem. 2008, 134, 585-590. [CrossRef]

7. Song, M.-J.; Yun, D.-H.; Jin, J.-H.; Min, N.-K.; Hong, S.-I. Comparison of Effective Working Electrode Areas on Planar and Porous Silicon Substrates for Cholesterol Biosensor. Jpn. J. Appl. Phys. 2006, 45, 7197-7202. [CrossRef]

8. Setzu, S.; Salis, S.; Demontis, V.; Salis, A.; Monduzzi, M.; Mula, G. Porous silicon-based potentiometric biosensor for triglycerides. Phys. Status Solidi 2007, 204, 1434-1438. [CrossRef]

9. Ikonen, T.; Nissinen, T.; Pohjalainen, E.; Sorsa, O.; Kallio, T.; Lehto, V.-P. Electrochemically anodized porous silicon: Towards simple and affordable anode material for Li-ion batteries. Sci. Rep. 2017, 7, 7880. [CrossRef] [PubMed]

10. Pirasteh, P.; Charrier, J.; Dumeige, Y.; Joubert, P.; Haesaert, S.; Haji, L. Further results on porous silicon optical waveguides at $1.55 \mu \mathrm{m}$. Phys. Status Solidi 2007, 204, 1346-1350. [CrossRef]

11. RoyChaudhuri, C. A review on porous silicon based electrochemical biosensors: Beyond surface area enhancement factor. Sens. Actuators B Chem. 2015, 210, 310-323. [CrossRef]

12. Dhanekar, S.; Jain, S. Porous silicon biosensor: Current status. Biosens. Bioelectron. 2013, 41, 54-64. [CrossRef] [PubMed]

13. Muller, E.I.; Muller, C.C.; Souza, J.P.; Muller, A.L.H.; Enders, M.S.P.; Doneda, M.; Frohlich, A.C.; Iop, G.D.; Anschau, K.F. Green microwave-assisted wet digestion method of carbohydrate-rich foods with hydrogen peroxide using single reaction chamber and further elemental determination using ICP-OES and ICP-MS. Microchem. J. 2017, 134, 257-261. [CrossRef]

14. Rosa, J.M.; Fileti, A.M.F.; Tambourgi, E.B.; Santan, J.C.C. Dyeing of cotton with reactive dyestuffs: The continuous reuse of textile wastewater effluent treated by Ultraviolet/Hydrogen peroxide homogeneous photocatalysis. J. Clean. Prod. 2015, 90, 60-65. [CrossRef]

15. Asghar, A.; Raman, A.A.A.; Daud, W.M.A.W. Advanced oxidation processes for in-situ production of hydrogen peroxide/hydroxyl radical for textile wastewater treatment: A review. J. Clean. Prod. 2015, 87, 826-838. [CrossRef]

16. Okuda, S.; Nishiyama, N.; Saito, H.; Katsuki, H. Hydrogen peroxide-mediated neuronal cell death induced by an endogenous neurotoxin, 3-hydroxykynurenine. Proc. Natl. Acad. Sci. USA 1996, 93, 12553-12558. [CrossRef] [PubMed]

17. Uttara, B.; Singh, A.V.; Zamboni, P.; Mahajan, R.T. Oxidative Stress and Neurodegenerative Diseases: A Review of Upstream and Downstream Antioxidant Therapeutic Options. Curr. Neuropharmacol. 2009, 7, 65-74. [CrossRef] [PubMed] 
18. Gorman, A.M.; McGowan, A.; O'Neill, C.; Cotter, T. Oxidative stress and apoptosis in neurodegeneration. J. Neurol. Sci. 1996, 139, 45-52. [CrossRef]

19. Chen, X.; Zhang, Q.; Cheng, Q.; Ding, F. Protective effect of salidroside against $\mathrm{H}_{2} \mathrm{O}_{2}$-induced cell apoptosis in primary culture of rat hippocampal neurons. Mol. Cell. Biochem. 2009, 332, 85-93. [CrossRef] [PubMed]

20. Deng, Y.; Zuo, Y. Factors affecting the levels of hydrogen peroxide in rainwater. Atmos. Environ. 1999, 33, 1469-1478. [CrossRef]

21. Song, H.; Ni, Y.; Kokot, S. A novel electrochemical biosensor based on the hemin-graphene nano-sheets and gold nano-particles hybrid film for the analysis of hydrogen peroxide. Anal. Chim. Acta 2013, 788, 24-31. [CrossRef] [PubMed]

22. Gimeno, M.P.; Mayoral, M.C.; Andres, J.M. A potentiometric titration for $\mathrm{H}_{2} \mathrm{O}_{2}$ determination in the presence of organic compounds. Anal. Methods 2013, 5, 1510-1514. [CrossRef]

23. Matsubara, C.; Kawamoto, N.; Takamura, K. Oxo[5, 10, 15, 20-tetra(4-pyridyl)porphyrinato]titanium(IV): An ultra-high sensitivity spectrophotometric reagent for hydrogen peroxide. Analyst 1992, 117, 1781-1784. [CrossRef]

24. Toyo'oka, T.; Kashiwazaki, T.; Kato, M. On-line screening methods for antioxidants scavenging superoxide anion radical and hydrogen peroxide by liquid chromatography with indirect chemiluminescence detection. Talanta 2003, 60, 467-475. [CrossRef]

25. Yang, X.; Xiao, F.B.; Lin, H.W.; Wu, F.; Chen, D.Z.; Wu, Z.Y. A novel $\mathrm{H}_{2} \mathrm{O}_{2}$ biosensor based on $\mathrm{Fe}_{3} \mathrm{O}_{4}-\mathrm{Au}$ magnetic nanoparticles coated horseradish peroxidase and graphene sheets-Nafion film modified screen-printed carbon electrode. Electrochim. Acta 2013, 109, 750-755. [CrossRef]

26. Guascito, M.R.; Chirizzi, D.; Malitesta, C.; Siciliano, T.; Tepore, A. Te oxide nanowires as advanced materials for amperometric nonenzymatic hydrogen peroxide sensing. Talanta 2013, 115, 863-869. [CrossRef] [PubMed]

27. Sivalingam, D.; Gopalakrishnan, J.B.; Krishnan, U.M.; Madanagurusamy, S.; Rayappan, J.B.B. Nanostructured $\mathrm{ZnO}$ thin film for hydrogen peroxide sensing. Phys. E Low-Dimens. Syst. Nanostruct. 2011, 43, 1804-1808. [CrossRef]

28. Gao, P.; Liu, D. Facile synthesis of copper oxide nanostructures and their application in non-enzymatic hydrogen peroxide sensing. Sens. Actuators B Chem. 2015, 208, 346-354. [CrossRef]

29. Chen, S.; Yuan, R.; Chai, Y.; Zhang, L.; Wang, N.; Li, X. Amperometric third-generation hydrogen peroxide biosensor based on the immobilization of hemoglobin on multiwall carbon nanotubes and gold colloidal nanoparticles. Biosens. Bioelectron. 2007, 22, 1268-1274. [CrossRef] [PubMed]

30. Arya, S.K.; Saha, S.; Ramirez-Vick, J.E.; Gupta, V.; Bhansali, S.; Singh, S.P. Recent advances in ZnO nanostructures and thin films for biosensor applications: Review. Anal. Chim. Acta 2012, 737, 1-21. [CrossRef] [PubMed]

31. Al-Hardan, N.H.; Abdul Hamid, M.A.; Shamsudin, R.; Othman, N.K.; Kar Keng, L. Amperometric Non-Enzymatic Hydrogen Peroxide Sensor Based on Aligned Zinc Oxide Nanorods. Sensors (Basel) 2016, 16, 1004. [CrossRef] [PubMed]

32. Zhou, J.; Xu, N.S.N.; Wang, Z.L.Z.L. Dissolving Behavior and Stability of ZnO Wires in Biofluids: A Study on Biodegradability and Biocompatibility of ZnO Nanostructures. Adv. Mater. 2006, 18, 2432-2435. [CrossRef]

33. Kumar, P.S.; Paik, P.; Raj, A.D.; Mangalaraj, D.; Nataraj, D.; Gedanken, A.; Ramakrishna, S. Biodegradability study and $\mathrm{pH}$ influence on growth and orientation of $\mathrm{ZnO}$ nanorods via aqueous solution process. Appl. Surf. Sci. 2012, 258, 6765-6771. [CrossRef]

34. Al-Hardan, N.H.; Jalar, A.; Abdul Hamid, M.A.M.A.; Keng, L.K.; Shamsudin, R.; Majlis, B.Y. The room-temperature sensing performance of $\mathrm{ZnO}$ nanorods for 2-methoxyethanol solvent. Sens. Actuators B Chem. 2014, 203, 223-228. [CrossRef]

35. Rahman, M.M.; Asiri, A.M. Development of selective and sensitive bicarbonate chemical sensor based on wet-chemically prepared CuO-ZnO nanorods. Sens. Actuators B Chem. 2015, 214, 82-91. [CrossRef]

36. Kumar, P.; Maikap, S.; Qiu, J.-T.; Jana, S.; Roy, A.; Singh, K.; Cheng, H.-M.; Chang, M.-T.; Mahapatra, R.; Chiu, H.-C.; et al. Detection of $\mathrm{pH}$ and Enzyme-Free $\mathrm{H}_{2} \mathrm{O}_{2}$ Sensing Mechanism by Using GdO Membrane in Electrolyte-Insulator Semiconductor Structure. Nanoscale Res. Lett. 2016, 11, 434. [CrossRef] [PubMed]

37. Kong, L.; Ren, Z.; Zheng, N.; Du, S.; Wu, J.; Tang, J.; Fu, H. Interconnected $1 \mathrm{D} \mathrm{Co}_{3} \mathrm{O}_{4}$ nanowires on reduced graphene oxide for enzymeless $\mathrm{H}_{2} \mathrm{O}_{2}$ detection. Nano Res. 2015, 8, 469-480. [CrossRef]

38. Niu, X.; Zhao, H.; Chen, C.; Lan, M. Platinum nanoparticle-decorated carbon nanotube clusters on screen-printed gold nanofilm electrode for enhanced electrocatalytic reduction of hydrogen peroxide. Electrochim. Acta 2012, 65, 97-103. [CrossRef] 
39. Kurowska, E.; Brzózka, A.; Jarosz, M.; Sulka, G.D.; Jaskuła, M. Silver nanowire array sensor for sensitive and rapid detection of $\mathrm{H}_{2} \mathrm{O}_{2}$. Electrochim. Acta 2013, 104, 439-447. [CrossRef]

40. Wang, T.; Zhu, H.; Zhuo, J.; Zhu, Z.; Papakonstantinou, P.; Lubarsky, G.; Lin, J.; Li, M. Biosensor based on ultrasmall $\mathrm{MoS}_{2}$ nanoparticles for electrochemical detection of $\mathrm{H}_{2} \mathrm{O}_{2}$ released by cells at the nanomolar level. Anal. Chem. 2013, 85, 10289-10295. [CrossRef] [PubMed]

41. Song, M.-J.J.; Hwang, S.W.; Whang, D. Non-enzymatic electrochemical CuO nanoflowers sensor for hydrogen peroxide detection. Talanta 2010, 80, 1648-1652. [CrossRef] [PubMed]

42. Han, K.N.; Li, C.A.; Bui, M.-P.N.; Pham, X.-H.; Kim, B.S.; Choa, Y.H.; Seong, G.H. Development of Pt/TiO 2 nanohybrids-modified SWCNT electrode for sensitive hydrogen peroxide detection. Sens. Actuators B Chem. 2012, 174, 406-413. [CrossRef]

43. Ensafi, A.A.; Abarghoui, M.M.; Rezaei, B. Electrochemical determination of hydrogen peroxide using copper/porous silicon based non-enzymatic sensor. Sens. Actuators B Chem. 2014, 196, 398-405. [CrossRef]

2018 by the authors. Licensee MDPI, Basel, Switzerland. This article is an open access article distributed under the terms and conditions of the Creative Commons Attribution (CC BY) license (http:/ / creativecommons.org/licenses/by/4.0/). 